\title{
PSEUDOMORPHIC CHARACTERS OF THE NOVEL "THE PHARMACIST" BY YURIY VYNNYCHUK IN THE CONTEXT OF CULTURAL TRADITION (CULTUROLOGICAL FACETS OF ANALYSIS)
}

\section{Oleksandra Nikolova, Kateryna Vasylyna}

\section{INTRODUCTION}

The value of the cultural aspect of philological analysis is determined by the prospects of research of artistic texts that reflect mankind's cultural heritage in the figurative form. Firstly, it is necessary to "decode" such achievements as iconic cultural phenomena accumulated during the development of a society in literary works in order to understand the nature of the interaction of tradition and innovation (diachronic approach). Secondly, the analysis of verbal works of art in the cultural context of the current era is carried out with the intention to elucidate those processes that determine the leading trends in the field of literature as a "document of its day" (synchronic approach). And, thirdly, comparative multidirectional studies allow us to rise to the level of broad generalizations and systematically comprehend the importance of certain cultural connections and typological similarities that explicitly attest to the existence of universal values, universal ideas, promote mutual understanding among representatives of different countries, ethnicities etc. And this is only to name a few potential possibilities of such studies.

According to N. Simbirtseva, "the cultural aspect of the philological analysis of a text can be characterized in terms of the values represented by the interaction and complementarity of the chain "time space - personality"; in terms of communication in the sociocultural space that embraces the dialogue of the author of an artwork with themselves, with history, with routine life etc., as well as the close and distant context of the literary text functioning; in terms of the subject-object relations of the writer and culture and the role that the creative individuality of the writer plays in the local sociocultural space" 1 .

${ }^{1}$ Simbirtseva N. A. (2007) Bytije literaturno-khudozhestvennogo proizvedenija: kulturologicheskij aspect [Functioning of a work of fiction: culturological aspect]. Vestnik Chelyabinskogo gosudarstvennogo universiteta, no. 14. P. 28. 
The interplay of cultural studies and philology has a long history, linked to the concept of "race, milieu, and moment" by H. Taine that was substantially enriched by the research of many scientific schools (e.g. "ritualists", representatives of the "Cambridge School" focused on establishing ritual sources of origin of literature, structuralists who are interested in decoding value orientations at the level of binary oppositions in a work of art, etc.), by such well-known scholars as M. Bakhtin ("The Creative Art of François Rabelais and Folk Culture of the Middle Ages and the Renaissance", "Problems of Dostoevsky's Poetics"), Y. Lotman ("The Semiotics of Culture and the Concept of a Text") and others. Unfortunately, it is impossible to provide comprehensive and holistic coverage of all the achievements in this field within the range of our article. However, everything stated before proves that the research in the chosen direction is viable and productive.

At present there are plenty of research papers in which the authors substantiate the importance of cultural studies for philology. For example, the abovementioned study by N. Simbirtseva in which the scholar explains her own methodology of studying literary texts in culturological light which is based on the well-known "theory of dialogue" by M. Bakhtin; T. Betsenko's research ${ }^{2}$ (that characterizes linguocultural approach); the one by L. Komarova ${ }^{3}$ (where important basic principles of cultural analysis of a literary text are identified with the view of concepts of B. Vokhrysheva and Y. Brazgovskaya) etc.

The purpose of this article is to study the novel "The Pharmacist" by Y. Vynnychuk with the view of the culturalogical aspect by selecting and characterizing the pseudomorphic characters of this piece in the context of cultural tradition.

To achieve the main purpose, it is necessary to combine synchronic, diachronic methods of culturology with the genetic and typological approaches of comparative studies in contextual facet.

${ }^{2}$ Betsenko T. (2017) Vydy analizu khudozhnoho tekstu [Types of a literary text analysis]. Visnyk Lvivskoho universytetu. Seriya filolohichna, vypusk 64, ch II. Pp. 239-244.

${ }^{3}$ Komarova L. I. Sovremennyje podhody k izucheniju hudozhestvennogo teksta [Modern approaches to studying a literary text]. Cyberleninka (electronic journal). Retrieved from: https://cyberleninka.ru/article/n/sovremennye-podhody-kizucheniyu-hudozhestvennogo-teksta (accessed: 24 January 2020). 


\section{Scientific background of the research: theoretical basis and main directions of studies that are relevant to solving the stated problem}

The range of phenomena potentially favorable for cultural studies in philology is very broad. Pseudomorphic characters are one of them as they deserve special attention of scholars interested in research of verbal art pieces (myths, folklore, literature) as well as their ceremonial and ritual sources in various cultural contexts (synchronic, diachronic, comparative ones).

Pseudomorphic characters (derived from the ancient Greek "pseudo" - "deceit", "fiction", "mistake" and "morpho" - "form") are the characters whose main feature is "falsehood created as a result of unnatural violation of the correspondence between their essence and its formal presentation / reception, that start to correlate with the opposite categories. Such characters temporarily acquire someone else's likeness, impersonate others, they are inadequately perceived ..." .

It is necessary to single out several main ways of pseudomorphic characters' creation.

“1) Cross-dressing (change of dress, disguise), most often aimed at visual change of gender or social status, i.e. cross-gender" and crossstatus travesty: in the first case, a girl / woman dresses as a man or, vice versa, a man wears a woman's dress, and in the second case the change of clothing indicates a formal transition of a person to another social group, class (in particular, when a noble man pretends to be a beggar, a rogue tries to mislead someone with an expensive suit, etc.).

2) Metamorphosis, accompanied only by a formal transformation with the preservation of the meaningful essence, that is, of consciousness, of intelligence of the person transformed (purely formal metamorphosis). For example, when as a result of magic (spell, voluntary transformation), a person acquires the likeness of an animal, a

${ }^{4}$ Nikolova O. O. (2017) Psevdomorfni personazhi ukrainskoi ta rosiiskoi literatur kintsia XVIII - pershoyi polovyny XIX st. (u konteksti yevropeiskoyi tradytsii). [Pseudomorphic Characters of Ukrainian and Russian Literatures of the Late $18^{\text {th }}-1^{\text {st }}$ Half of the $19^{\text {th }}$ C. (in the Context of European Tradition)]. Zaporizhzhya : Zaporizkyi natsionalnyi universytet. p.5. (in Ukrainian).

${ }^{5}$ Osinovskaya O. S. Kross-gendernoje pereodevanije v pjesah U. Shekspira [Cross-gender change of attire in plays by W. Shakespeare]. Literatures and Languages (electronic journal), vol. 21. Retrieved from: http://svr-lit.ru/svrlit/articles/english/osinovskaya-kross-gendernoe-pereodevanie.htm (accessed: 31 January 2020). 
bird, a plant, and so on, while retaining the ability of thinking, talking and feeling in a human way, or when a supernatural creature appears in an anthropomorphic form to conceal its true nature (humanization of gods, demons, spirits, etc.) ...

3) A verbal and positional pretention aimed at creating a holistic illusion that can accompany travesty, transformation or substitute them.

In the latter case, the character turns to deceptive verbal and behavioral self-presentation and tries to impersonate the other person thus shows unusual mental abilities, moral qualities or, on the contrary, conceals them to produce an impression of one's own importance or worthlessness, etc.

4) Situational mismatch (incongruence between one's essence and its presentation or its perception) means that pseudomorphism arises as a result of a coincidence, play of chance, confusion, misidentification, substitution made by someone else and so on"6.

The potential of the cultural studies of this subject "is predominantly defined by its universal nature: on the one hand, it functions on all the levels of the "triad" of "myth/ ritual - folklore literature" and, on the other hand it is widely-spread at different times in numerous national cultures" and the visually receptive things is one of the eternal themes in creative works of many peoples" ${ }^{\prime}$.

However, despite "popularity" of such characters, comprehensive coverage of the issues of their genesis, criteria of systematization, ways of distribution, trends of transformation, etc. has evolved only recently.

The monograph "Pseudomorphic Characters of Ukrainian and Russian Literatures of the Late $18^{\text {th }}-1^{\text {st }}$ Half of the $19^{\text {th }} \mathrm{C}$. (in the Context of European Tradition)" is the first attempt at systematic study of these

${ }^{6}$ Nikolova O. O. (2017) Psevdomorfni personazhi ukrainskoi ta rosiiskoi literatur kintsia XVIII - pershoyi polovyny XIX st. (u konteksti yevropeiskoyi tradytsii). [Pseudomorphic Characters of Ukrainian and Russian Literatures of the Late $18^{\text {th }}$ $1^{\text {st }}$ Half of the $19^{\text {th }}$ C. (in the Context of European Tradition)]. Zaporizhzhya : Zaporizkyi natsionalnyi universytet. P. 24 (in Ukrainian).

${ }^{7}$ Ibid, p. 22.

${ }^{8}$ Nikolova O. O. (2017) Psevdomorfni personazhi ukrainskoi ta rosiiskoi literatur kintsia XVIII - pershoyi polovyny XIX st. (u konteksti yevropeiskoyi tradytsii). [Pseudomorphic Characters of Ukrainian and Russian Literatures of the Late $18^{\text {th }}-$ $1^{\text {st }}$ Half of the $19^{\text {th }} \mathrm{C}$. (in the Context of European Tradition)]. Zaporizhzhya : Zaporizkyi natsionalnyi universytet. P. 5. (in Ukrainian). 
issues in a limited cultural and historical context ${ }^{9}$. Its conclusions are based on the author's own observations of the trends of functioning of the relevant phenomenon as well as on the achievements of well-known scientists who analyze certain facts in different fields of culture that are either directly or indirectly related to it.

Taking into account a great amount of such papers and without indulging in detailed analysis of each and every one of them, it is possible to categorize them into several groups in accordance with the object of research.

The first group is represented by the studies of the authors who analyze rituals associated with cross-dressing, masking, role swap, imitations, i.e. effective ways of creating temporary dissonance between the visible and the real, the formal and the essential. Works by J. G. Frazer ${ }^{10}$, F. M. Cornford ${ }^{11}$, M. Bakhtin ${ }^{12}$ and others present research of this kind. Scholars often stress upon the links between such rituals and the mythological, folklore and fictional images. The second group is exemplified by the studies of mythologists and folklorists (e.g. I. Sazonovich ${ }^{13}$, Y. Krzhizhanovskiy ${ }^{14}$ ) that are devoted to different characters who pretend to be someone else. The third group is presented by the literary criticism carried out in broad cultural

9 Nikolova O. O. (2017) Psevdomorfni personazhi ukrainskoi ta rosiiskoi literatur kintsia XVIII - pershoyi polovyny XIX st. (u konteksti yevropeiskoyi tradytsii). [Pseudomorphic Characters of Ukrainian and Russian Literatures of the Late $18^{\text {th }}-$ $1^{\text {st }}$ Half of the $19^{\text {th }}$ C. (in the Context of European Tradition)]. Zaporizhzhya : Zaporizkyi natsionalnyi universytet. 450 p. (in Ukrainian).

${ }^{10}$ Frazer J. G. (2001) Zolotaja vetv: issledovanije magii i religii v dvuh tomah [Golden bough: a study of magic and religion in two volumes]. Moskva : TERRA Knizhnyj klub, vol. 1. Pp. 379-386 (in Russian).

${ }^{11}$ Cornford F. M. (1914) The Origin of Attic Comedy. London : EDWARD ARNOLD. Pp. 132-137.

12 Bakhtin M. M. (1990) Tvorchestvo Fransua Rable i narodnaya kultura Srednevekovya i Renessansa [The Creative Art of François Rabelais and Folk Culture of the Middle Ages and the Renaissance]. Moskva: Hudozhestvennaja literatura. 543 p. (in Russian).

13 Sazonovich I. P. (2011) Pesni o devushke-voine $i$ byliny o Stavre Godinoviche : issledovanije po istorii razvitija slavjano-russkogo eposa [Songs about a girl-warrior and epics about Stavr Godunovich]. Moskva : Kniga po Trebovaniju. 183 p. (in Russian).

${ }^{14}$ Krzhizhanovskiy Y. (1963) Devushka-yunosha (k istorii motiva «peremena pola») [A girl-boy (history of the "gender change" motive)]. Russkij folklor, vol. 8. Pp. 56-66. 
context and focused on the characters' travesty in concrete pieces of literature (O. Osinovskaya ${ }^{15}$, G. Uliura $^{16}$, etc.), transformation $\left(\right.$ R. Krokhmalny ${ }^{17}$ ), imposture (Y. Makarenko ${ }^{18}$, M. Lazutkina ${ }^{19}$ ) and so forth.

The monograph "Pseudomorphic Characters of Ukrainian and Russian Literatures of the Late $18^{\text {th }}-1^{\text {st }}$ Half of the $19^{\text {th }} \mathrm{C}$. (in the Context of European Tradition)" 20 suggests a detailed review of the essence of the concepts of all the above mentioned scientists, as well as of other scholars that are meaningful for understanding the nature of pseudomorphic characters. A theoretical and methodological basis for research of this phenomenon is also accessible there ${ }^{21}$.

15 Osinovskaya O. S. Kross-gendernoje pereodevanije v pjesah U. Shekspira [Cross-gender change of attire in plays by W. Shakespeare]. Literatures and Languages (electronic journal), vol. 21. Retrieved from: http://svr-lit.ru/svr-lit/articles/english/ osinovskaya-kross-gendernoe-pereodevanie.htm (accessed: 31 January 2020).

16 Uliura A. (2004) Henderno markyrovannoje pereodevanije kak komicheskoje (na materiale russkoj klassicheskoj literatury) [Gender-marked crossdressing as the comic (case study: Russian classical literature)]. "Dóxa / DOKSA». Zbirnyk naukovykh prats z filosofii ta filolohii, vol. 5. Pp. 335-342.

17 Krokhmalnyi R. O. (2005) Metamorfoza $i$ tekst: semantychna, strukturotvorcha $i$ svitohlyadna rol pereminy khudozhnoho obrazu [Metamorphosis and the text: semantic, structure-making and worldview role of changing a literary image]. Lviv : Vydavnychyi tsentr Lvivskoho nats. un-tu imeni Ivana Franka. 424 p. (in Ukrainian).

${ }^{18}$ Makarenko Y. K. (2002) Zhanrovyj aspekt sjuzheta samozvanstva v russkoy dramaturgii $i$ istoriografii kontsa XVIII - pervoj treti XIX $v v$. [The genre aspect of the plot about impostor in Russian dramaturgy and historiographics of the late XVIII early XIX centuries] (PhD Thesis). Tomsk, $21 \mathrm{p}$.

19 Lazutkina M. G. (2003) Formirovanije hudozhestvennogo obraza samozvantsa Lzhedmitrija I v russkoj literature XVII - XIX vekov [Formation of a fictional image of the impostor Pseudo-Dmitrij I in Russian Literature of XVII XIX centuries] (PhD Thesis), Moskva, $19 \mathrm{p}$.

${ }^{20}$ Nikolova O. O. (2017) Psevdomorfni personazhi ukrainskoi ta rosiiskoi literatur kintsia XVIII - pershoyi polovyny XIX st. (u konteksti yevropeiskoyi tradytsii). [Pseudomorphic Characters of Ukrainian and Russian Literatures of the Late $18^{\text {th }}$ $1^{\text {st }}$ Half of the $19^{\text {th }}$ C. (in the Context of European Tradition)]. Zaporizhzhya : Zaporizkyi natsionalnyi universytet. pp. 12 - 19 (in Ukrainian).

${ }^{21}$ Nikolova O. O. (2017) Psevdomorfni personazhi ukrainskoi ta rosiiskoi literatur kintsia XVIII - pershoyi polovyny XIX st. ( $u$ konteksti yevropeiskoyi tradytsii). [Pseudomorphic Characters of Ukrainian and Russian Literatures of the Late $18^{\text {th }}$ $1^{\text {st }}$ Half of the $19^{\text {th }}$ C. (in the Context of European Tradition)]. Zaporizhzhya : Zaporizkyi natsionalnyi universytet. Pp. 22 - 140. (in Ukrainian). 
As concerns the prospects of pseudomorphic characters' analysis, it is worthwhile mentioning that "research carried out within other .... literary trends, cultural epochs promises interesting findings in the field" ${ }^{22}$. This emphasizes the expediency of broadening the object range of such studies.

This article is aimed at the analysis of pseudomorphic characters in the novel "The Pharmacist" by the contemporary writer Yurii Vynnychuk who is a significant figure in Ukrainian culture of the $21^{\text {st }}$ century. He is known as a journalist, interpreter, editor and the author of a lot of novels ("Malva Landa", "Springtime Games in Autumn Gardens", "Pears in Dough", "Tango of Death", "The Pharmacist", "Sisters of Blood", "Lutetia", etc.), he has been awarded with literary prizes ("Golden Ukrainian Writers", "BBC Book of the Year").

"The Pharmacist" (2015) by Y. Vynnychuk attracts the attention of critics and scholars who analyse different aspects of the novel: Y. Vitiak ${ }^{23}$, O. Kotsarev ${ }^{24}$, T. Litvinchuk ${ }^{25}$, A. Panchenko ${ }^{26}$, I. Tsikhotskii and I. Borosovska ${ }^{27}, \mathrm{~S}$. Cherniuk ${ }^{28}$ etc.

${ }^{22}$ Ibid, p. 387.

23 Vitiak Y. (2016) Literaturna farmatsevtyka. Mizh panatseieiu i platsebo [Literary pharmaceuticals. Between the panacea and placebo]. Literaturnyi Ternopil, no 2, pp. 83-84.

${ }^{24}$ Kotsarev O. «Aptekar» Vynnychuka: vidmy, katuvannia, strashni mahichni knyzhky, balzamy, otruty i troshky seksu ["The Pharmacist" by Vynnychuk: witches, tortures, horrible magic books, balms, poisons and a little sex]. Тексти.org.иа [Texts.org.ua] (electronic journal). Retrieved from: http://texty.org.ua/pg/article/ editorial/read/63534/Aptekar_Vynnychuka_vidmy_katuvanna_strashni_magichni_kny zhky (accessed 10 January 2020).

${ }^{25}$ Litvinchuk T. V. (2017) Lokus domu v serednovichnomu Lvovi (na materiali romanu «Aptekar» Yuriia Vynnychuka) [Locus of home in medieval Lviv (Yurii Vynnychuk's "The Pharmacist": case study)]. Literaturoznavchi studii, vol. 1(2), pp. 32-40.

${ }^{26}$ Panchenko A. (2016) Chytajem ukrainskoje: Retsenzija na knigu «Aptekar» Yurija Vinnichuka [Reading Ukrainian: review of the book "The Pharmacist" by Yurii Vynnychuk]. Segodnia [Today] (electronic journal). Retrieved from: https:// ukr.segodnya.ua/lifestyle/showbiz/chitaem-ukrainskoe-recenziya-na-knigu-aptekar-yuriyavinnichuka-701314.html (accessed 20 December 2019).

27 Tsikhotskii I., Borosovska I. (2018) Starolvivska beletrystyka Yuriia Vynnychuka: avtorska kontseptsiya movnoho istoryzmu (na materiali romanu «Aptekar») [Old-Lviv belles-lettres by Yurii Vynnychuk: author's concept of language historicism (novel "The Pharmacists": case study)]. Visnyk Lvivskoho universytetu. Seriya filolohichna, vol. 68, pp. 30-47. 
Regardless of the point of view, the majority of scientists claim that "The Pharmacist" exposes a strong connection with the cultural context: "communicative rhizomatics",29, intertextuality, "dialogism" with the "texts" of different eras and countries.

According to S. Cherniuk, the "encyclopedia" (according to U. Eco) of the implicit reader of "The Pharmacist" may a priori contain not only the works of the sixtiers-eightiers but also an immense (and indefinite) list of foreign authors, most obviously of "Perfume" by Patrick Süskind, "Decameron" by Giovanni Boccaccio, or of oriental fairy tales for sure by Wilhelm Hauff, "The Name of the Rose" by Umberto Eco, "The Witches of Eastwick" by John Updike, of important proto-texts outlined by the writer himself" ${ }^{30}$. The scholar also emphasizes the correlation of the novel with different genre forms: of "mass literature such as adventure, rogue, detective, love, fantastical, thrash, thriller, of black humor, folk-medicine, as well as of the ones aimed at a more experienced reader e.g. historical, political, historical medical, alchemical-apothecary, philosophical, antiquary or, more broadly, with meta-prose literature, literature about literature" $" 31$.

At the same time, despite the popularity of "The Pharmacist" among the scientific community of Ukraine, the question of functioning of pseudomorphic characters in its artistic world still remains unsettled. However, S. Cherniuk points out that the image of the "travesty transvestite Yuliana-Lorenzo" evokes associations with Boccaccio's "Decameron" and works by Shakespeare: "the intertextuality of both names may have been due to the combination of the names of the two Medici brothers, of whom Lorenzo was, among other things, a writer who had active dispute with Savonarola"32.

${ }^{28}$ Cherniuk S. L. (2016) Komunikatsiina ryzomatyka romanu Y. Vynnychuka «Aptekar» [Communication rhizomatics of Yurii Vynnychuk's novel "The Pharmacist"]. Nuakovi pratsi Chornomorskogo derzhavnoho universytetu imeni Petra Mohyly kompleksu "Kyevo-Mohylianska Akademiia”, vol. 276, no. 264, pp. 121-126. Retrieved from: http://nbuv.gov.ua/UJRN/Npchdufl_2016_276_264_23 (accessed 11 November 2019).

${ }^{29}$ Ibid.

${ }^{30}$ Ibid.

${ }^{31}$ Ibid.

${ }^{32}$ Cherniuk S. L. (2016) Komunikatsiina ryzomatyka romanu Y. Vynnychuka «Aptekar» [Communication rhizomatics of Yurii Vynnychuk's novel "The Pharmacist"]. Nuakovi pratsi Chornomorskogo derzhavnoho universytetu imeni Petra 
However, there is still no comprehensive, systematic coverage of the problem in its cultural aspect accompanied by a convincing argumentation of the traditional character of the motives of impersonation and pretention used by Y. Vynnychuk. Our research is intended to fill the existing lacuna.

\section{Cross-gender travesty (the image of Yuliana-Lorenzo) in the context of cultural tradition}

There are different pseudomorphic characters acting in "The Pharmacist". The most notable is the image of a girl Yuliana by name who engages herself in cross-gender travesty: she pretends to be a young man named Lorenzo in order to obtain medical education, to master a "male" profession of a surgeon (the action is set in the $17^{\text {th }}$ century) and to revenge upon her sister's murderer.

"Surgery? I have some grasp of it. Because I studied at the university in Padua. - It's impossible! No women can enter there. - And who told you that I was a woman? I was a boy. I got disguised as a boy and so I studied during all those years" ${ }^{33}$.

While playing her male role for a long time, Yuliana not only learned how to perform operations, fence skillfully and speak in a rough voice, but also got rid of a purely female vulnerability and sensuality: "I've learned to be cold, and no death will ever move me" ${ }^{34}$. So, it is not surprising that the heroine kills all her sister's rapists, one by one, she does it in cold blood and, having completed her revenge, she leaves the city unsuspected and unhindered.

The image of Yuliana-Lorenzo neatly fits into the context of cultural tradition, since the history of cross-gender travesty goes back to ancient rites, continues its development in myths and folklore of different peoples. It is also enriched by many attributes due to the development of literature, in the first place, and later through cinematography.

Though there is a debate among scholars about the essence of ritual and ceremonial dressing in the attire of the opposite sex, still everyone

Mohyly kompleksu “Kyevo-Mohylianska Akademiia”, vol. 276, no. 264, pp. 121-126. Retrieved from: http://nbuv.gov.ua/UJRN/Npchdufl_2016_276_264_23 (accessed 11 November 2019).

${ }^{33}$ Vynnychuk Y. (2015) Aptekar [The Pharmacist]. Kharkiv: Folio, p. 183 (in Ukrainian).

${ }^{34}$ Ibid, p. 184. 
acknowledges the fact of its existence in many cultures. For example, V. Propp points out that this custom "has been extremely widespread throughout Europe since antiquity"35, but "it is difficult to explain, and there is no complete clarity in its meaning and sense till this day" 36 . M. Bakhtin argues that this phenomenon is typical of carnival performances related to the destruction of traditional social norms: "We observe it first of all in the participants' clothes. Men are dressed as women and vice versa..."37. O. Freidenberg interprets "female-male travesty" as a metaphor of sexual contact: "a woman becomes a man, a man becomes a woman" 38 .

The range of folklore genres in which the corresponding motifs are used to the best effect is quite wide and embraces ballads, songs, epics, romances, fairy tales, legends and so on. For example, $\mathrm{O}$ Miller $^{39}$, I. Franko ${ }^{40}$, I. Sazonovich ${ }^{41}$, Y. Krzhizhanovskiy ${ }^{42}$ and others pay special attention to the "popularity" of the image of a "maiden warrior" in the folk art of different countries. The international system of classification of fairy tales suggested by A. Aarne and S. Thompson singles out the plots of such types as: "The

35 Propp V. Y. (2000) Russkije agrarnyje prazdniki. Opyt istorikoetnograficheskogo issledovanija [Russian agrarian holidays. Experience of historical and ethnographic research]. Moskva : Labirint, p. 137 (in Russian).

${ }^{36}$ Ibid, p. 137.

37 Bakhtin M. M. (1990) Tvorchestvo Fransua Rable i narodnaya kultura Srednevekovya i Renessansa [The Creative Art of François Rabelais and Folk Culture of the Middle Ages and the Renaissance]. Moskva: Hudozhestvennaja literature, p. 454 (in Russian).

${ }^{38}$ Freidenberg O. M. (1997) Poetika sjuzheta i zhanra [Poetics of plot and genre]. Moskva : Labirint, p. 95 (in Russian).

${ }^{39}$ Miller O. F. (1869) Ilja Muromets i bogatyrstvo Kijevskoje [Ilya Muromets and Kyiv bogatyrs]. Sankt-Peterburg : Tipografija N. N. Mikhajlova, p. 635-637 (in Russian).

${ }^{40}$ Franko I. (1984) Divchyna-voiachka [A girl-warrior]. Zibrannia tvoriv $u$ 50 -ty $t$. [Collection of works in 50 volumes]. Kyiv : Naukova dumka, vol. 42, pp. 225-229.

41 Sazonovich I. P. (2011) Pesni o devushke-voine i byliny o Stavre Godinoviche : issledovanije po istorii razvitija slavjano-russkogo eposa [Songs about a girl-warrior and epics about Stavr Godunovich]. Moskva : Kniga po Trebovaniju, 183 p. (in Russian).

${ }^{42}$ Krzhizhanovskiy Y. (1963) Devushka-yunosha (k istorii motiva «peremena pola») [A girl-boy (history of the "gender change" motive)]. Russkij folklor, vol. 8 . pp. 56-66. 
Abandoned Bride Disguised as a Man" AT 881, "The Forsaken Fiancée: Service as a Menial" AT 884, "The Girl as Soldier" AT 884 etc. The fairytale plot "The Active Heroine Disguised as a Man Saves a Man from Trouble" (AT 880, 881, 881A, 882, 883B, 887, 888, $888 \mathrm{~A})$ is analyzed in detail by Ye. Meletinskiy ${ }^{43}$.

As for literary studies, according to G. Uliura, "the theme of crossdressing (in the broadest sense of the term ranging from the change of social status to carnivalization of gender) is probably the most important and nearly the least studied of all the variety of topics that form the field of interest of gender studies in literary criticism" "44. This gap is to some extent filled by the results of the research presented in the monograph "Pseudomorphic Characters of Ukrainian and Russian Literatures of the Late $18^{\text {th }}-1^{\text {st }}$ Half of the $19^{\text {th }}$ C. (in the Context of European Tradition)", which highlights quite a number of works of art that use this material.

It is necessary to note that "Literary life of various motives with cross-gender dressing continues in novelistics (the third and ninth novellas of the second day of "Decameron" by Giovanni Boccaccio, "The Novel of How the Revelation Source was Discovered" by A. de Eslava, "New Pastimes and Merry Chats" by Bonaventure des Périers, "Pachecos and Palomeques" by Gonzalo de Céspedes y Meneses, "El Patrañuelo" by Juan de Timoneda, "The Fortunes of Diana" by Lope de Vega, etc.), dramaturgy ("Castrucho the Pimp" by Lope de Vega, ... "Life is a Dream" by Pedro Calderón de la Barca, "Don Gil of the Green Breeches" by T. de Molina, "The Servant of Two Masters" by C. Goldoni, "The Merry Wives of Windsor", "The Merchant of Venice", "The Two Gentlemen of Verona", "The Twelfth Night or What You Will", "As You Like It" by W. Shakespeare, "The Headstrong Woman" by H. KvitkaOsnovianenko etc.), stories and novels ("Natalia, the Boyar's Daughter" by M. Karamzin, "Chaikovskii" by Y. Hrebinka, "The Foundation of Kharkov" by H. Kvitka-Osnovianenko), hagiographical literature ("The Life of Reverend Apollinaria", "The Life of Our Reverend Mother Xenia"... and others) etc.

${ }^{43}$ Meletinskiy Ye. (1990) Istoricheskaja poetika novelly [Historical poetics of novella]. Moskva: Nauka, p. 13 (in Russian).

44 Uliura A. (2004) Henderno markyrovannoje pereodevanije kak komicheskoje (na materiale russkoj klassicheskoj literatury) [Gender-marked crossdressing as the comic (case study: Russian classical literature)]. "Dóxa / DOKSA». Zbirnyk naukovykh prats z filosofii ta filolohii, vol. 5, p. 335. 
In the last of the genre traditions listed above, dressing of a woman in men's attire is prompted by her desire to serve God" "45.

Scholars also testify the spread of "Popesse Joanna" plot in WestEuropean and East-Slavic literatures: it is about the seizure of "papal authority by a young woman who obtains (due to good theological education received by her in a male likeness) a high position in Catholic hierarchy and even the papal throne for some time, from which she is dismissed by the angry people"

O. Osinovskaya, while analyzing tendencies in the functioning of cross-gender travesty in Shakespeare's plays, states the following: "...usage of "someone else's" clothing results either in increase or decrease of one's status. A man, putting on women's clothing, lost those powers, rights and authority that the "strong" sex usually possesses... Women, on the contrary, receive much more mobility in men's clothing. They become more influential in their new environment" 47 , they acquire many more rights: women's crossdressing as the one directed up the social hierarchy of Elizabethan society is justified and rewarded ${ }^{48}$.

In general, the analysis of the cultural tradition associated with the usage of plots in which a girl imitates a man gives possibility to identify several leading motives of such travesty: 1) love (rescue or return of a loved one, of a man); 2) desire to establish justice (revenge on the traitor, slanderer, criminal, etc.); 3) fight for gender equality, i.e. desire to "prove one's suitability for some serious, "male" business, profession, etc." "49.

45 Nikolova O. O. (2017) Psevdomorfni personazhi ukrainskoi ta rosiiskoi literatur kintsia XVIII - pershoyi polovyny XIX st. ( $u$ konteksti yevropeiskoyi tradytsii). [Pseudomorphic Characters of Ukrainian and Russian Literatures of the Late $18^{\text {th }}-$ $1^{\text {st }}$ Half of the $19^{\text {th }}$ C. (in the Context of European Tradition)]. Zaporizhzhya : Zaporizkyi natsionalnyi universytet. p. 63 (in Ukrainian).

${ }^{46}$ Veselovsky A. N. (1870) Starinnyj teatr $v$ Yevrope [Ancient theatre in Europe]. Moskva : V tipografii P. Bakhmeteva, p. 59 (in Russian).

${ }^{47}$ Osinovskaya O. S. Kross-gendernoje pereodevanije v pjesah U. Shekspira [Cross-gender change of attire in plays by W. Shakespeare]. Literatures and Languages (electronic journal), vol. 21. Retrieved from: http://svr-lit.ru/svr-lit/articles/english/ osinovskaya-kross-gendernoe-pereodevanie.htm (accessed: 31 January 2020).

48 Ibid.

49 Nikolova O. O. (2017) Psevdomorfni personazhi ukrainskoi ta rosiiskoi literatur kintsia XVIII - pershoyi polovyny XIX st. ( $u$ konteksti yevropeiskoyi tradytsii). [Pseudomorphic Characters of Ukrainian and Russian Literatures of the Late $18^{\text {th }}$ $1^{\text {st }}$ Half of the $19^{\text {th }}$ C. (in the Context of European Tradition)]. Zaporizhzhya : Zaporizkyi natsionalnyi universytet. P. 64 (in Ukrainian). 
The presence of the pseudo-Lorenzo in Y. Vynnychuk's novel is not in any way connected with love, at the same time two other motives remain relevant, which demonstrates the peculiar "emancipation" of the heroine, whose need for self-realization, professional growth and protection of her sister's honor are of paramount importance. So, crossgender travesty is a consequence of Yuliana's awareness of the need to fight for women's rights in patriarchal society (the right for education, work, justice). Everything mentioned above gives reason to integrate this cross-dressing plot of "The Pharmacist" in the cultural context of modernity, because Yuliana's position represents the position of a Ukrainian woman of the $21^{\text {st }}$ century rather than that of a girl of the $17^{\text {th }}$ century.

The so-called "motive of deception of feelings" 50 , typical of the cultural tradition, is also updated in the novel. It is the case when a pseudomorphic character evokes the sympathy of a representative of their own sex, who is not aware of the fraud.

The corresponding narrative cliché is used, for example, in Novella III (LXXIV 1-3) of "Novellino", "Castrucho the Pimp", "The Fortunes of Diana" by Lope de Vega, "Anconitanka" by A. Beolko, "The Adventures of a Beautiful Muslim Woman" by Antoine François Prévost d'Exiles, "The Twelfth Night, or What You Will" by W. Shakespeare and many more. Analyzing this motif in a comedy by W. Shakespeare, O. Anikst notes that the "triangle" of "Olivia - Orsino - Viola" was borrowed from Barnaby Rich ("Farewell to Military Profession", 1581), at the same time this plot-line had a long life: "It first appeared in the Italian comedy "The Confused" (1531), then in one of the novels by Bandello (1554), from which it passed over to François de Belleforest and from there it arrived in England"51.

Such "deception of feelings" is generally typical of the Renaissance drama: "A hero is in love, the subject of his passion has affection to another one who (the girl disguised as a man) has given the heart to a boy who is in love without reciprocity ("The Deceived"). It is clear that no one can get out of this maze without loss unless a fourth partner is involved

50 Anikst A. (1989) Dvenadtsataya noch, ili Chto ugodno [Twelfth Night or What you will]. Angliyskaya komediya XVII - XVIII vekov : antologiya [English comedy of 17th-18th centuries]. Moskva: Vysshaya shkola, p. 736.

51 Anikst A. (1989) Dvenadtsataya noch, ili Chto ugodno [Twelfth Night or What you will]. Angliyskaya komediya XVII - XVIII vekov : antologiya [English comedy of $17^{\text {th }}-18^{\text {th }}$ centuries]. Moskva: Vysshaya shkola, p. 735. 
who would accept love that is non-productive, aimed at a representative of the same-sex, that is, unless a circular structure is transformed into a paired one (and the fourth part, the twin-brother of that girl who has adopted another gender is sure to appear), ${ }^{, 52}$.

In the novel by Y. Vynnychuk a country girl Ruta falls in love with Yuliana-Lorenzo and she is sure that it is the best man in the world. "Stammering and hurrying, missing words and individual sounds, Ruta confessed her feelings to Lorenzo, starting with the fact that it had happened to her for the first time, that she had never loved anyone so much, all the time since Lorenzo appeared in her life, she had loved him, and it seemed to her that he might also have some feelings to her" ${ }^{\prime 53}$. At the same time the situation is getting more complicated because the pharmacist (Lukash) sympathizes with Yuliana as a girl.

However, while in the classic version of the plot the conflict is resolved in a traditional way, it is otherwise settled in the novel by Y. Vynnychuk. An unexpected thing happens as soon as all the truth about the gender of the "fair knight" is revealed: Yuliana kisses the girl named Ruta. "Juliana pressed Ruta to her breast and kissed her on the lips with such passion that Ruta got dizzy ..." ${ }^{, 54}$. But in the finale of the novel Ruta at last realizes that it is Lukash who is her true love. Thus after disappearance of pseudo-man Yuliana, the boy and the girl who used to be in love with her finally find each other.

\section{Franz and Lukash as pseudomorphic characters and carnivalesque nature of the novel in the context of cultural tradition}

Another pseudomorphic character of "The Pharmacist" is a devil that during the development of action in the piece pretends to be an ordinary man. The infernal creature turns into an attractive young man named Franz: “.. a skinny, slender young master dressed in German fashion came into the house ... - Ah, it's you, rascal - the witch

${ }^{52}$ Andreyev M. L., Khlodovskiy R. I. (1988) Italyanskaya literatura zrelogo $i$ pozdnego Vozrozhdeniya [Italian literature of high and late Renaissance]. Moskva : Nauka, p. 181 (in Russian).

${ }^{53}$ Vynnychuk Y. (2015) Aptekar [The Pharmacist]. Kharkiv: Folio, p. 235 (in Ukrainian).

${ }^{54}$ Ibid, p. 285. 
recognized the familiar devil, who hadn't visited her for a long time" ${ }^{, 55}$. It is in this appearance that he stays among people.

The cultural tradition connected with the idea of the possibility of humanization of supernatural creatures (gods, spirits, demons, etc.) who in an anthropomorphic form are unrecognized and act in the earthly world, is rooted in ancient times: many myths and folklore of different peoples are illustrative in this respect ${ }^{56}$. "... the motive of deceptive humanization of a demonic creature can be associated with the typical Christian notion of the devil as a fraudster who resorts to various tricks to ruin as many souls as possible. Numerous fairytales, legends and ballads of different nations tell how the constant antagonist of God travels the world in the image of a human, tempting the credulous and indulging their passions" 57 .

In the fiction of the $18^{\text {th }}-20^{\text {th }}$ centuries the image of a humanized infernal is often associated with such motive as "a man makes a deal with the devil": here it is necessary to mention J. W. Goethe ("Faust"), J. Cazotte ("The Devil in Love"), A. von Chamisso ("Peter Schlemihl's Miraculous Story"), V. Hauff ("The Cold Heart"), M. Gogol ("Evening on the Eve of Ivan Kupala"), M. Zagoskin ("The Tempter"), L. Andreev ("Diary of Satan"), J. Krus ("Timm Thaler, or the Traded Laughter"), M. Bulgakov ("The Master and Margarita") etc.

The image of the anthropomorphic devil was created by Y. Vynnychuk in accordance with the best examples of this cultural tradition: there are many significant allusions in the text of "The Pharmacist" that actualize associations with various works that form the context of "cultural demonology".

For example, an intimate friendship with the witch is depicted in the spirit of "The Night Before Christmas" by M. Gogol: Franz and Vivdia drink vodka together, eat bacon and talk about life as old companions. Emphasis on the German costume as well as the German name of the devil, his role of a "servant" of the alchemist named

${ }^{55}$ Vynnychuk Y. (2015) Aptekar [The Pharmacist]. Kharkiv: Folio, p. 40 (in Ukrainian).

${ }^{56}$ Nikolova O. O. (2017) Psevdomorfni personazhi ukrainskoi ta rosiiskoi literatur kintsia XVIII - pershoyi polovyny XIX st. (u konteksti yevropeiskoyi tradytsii). [Pseudomorphic Characters of Ukrainian and Russian Literatures of the Late $18^{\text {th }}-$ $1^{\text {st }}$ Half of the $19^{\text {th }}$ C. (in the Context of European Tradition)]. Zaporizhzhya : Zaporizkyi natsionalnyi universytet. p.p. 85-88 (in Ukrainian).

${ }^{57}$ Ibid, p. 91. 
Kalkbrenner reminds a knowledgeable reader not only of J. W. Goethe's "Faust", but also of the chapbook "Historie of Johann Faust, the Infamous Magician and Necromancer" (as Kalkbrenner's name is Johann). Vivdia's salvation from prison, eagerness to find the murderers of Yuliana's sister, to help the innocent Lukash, who is at risk of execution ("I can sometimes go against my principles and do a good deed"58), all these events allow to draw parallels between Franz's image and M. Bulgakov's "kind" Woland. Mentioning "my friend Pilate" is also reminiscent of "The Master and Margarita".

Y. Vynnychuk's pseudomorphic character is not an embodiment of absolute evil, he is rather a cunning rogue, a trickster, a joker: in this aspect he looks like a travesty devil, the "crook, mocker, brawler" of folk theatre, fairy tales and legends ${ }^{60}$.

Franz gladly pokes fun at the sermons in the church, knows how to insert a sharp word in time; his favorite sphere is a play on the verge of illusion and reality, when the boundary between common norms and ideas is blurred: in such a carnival atmosphere, the hellish rogue feels quite organic. Therefore, among all masks for the holiday of Morana (something like modern Halloween), he chooses the most suitable one and that is of his own visage: "you will be a very nice vampire. I will be a werewolf, Amalia will be an old witch, and Franz... well, Franz will be...- Oh, dear Johann, - Franz grimaced, blushing pretentiously and putting on his devil mask, - you should not make wrongful use of name. I'll be just Franz"61.

At the same time, the humanized infernal creature of "The Pharmacist" as well as Yuliana-Lorenzo, seems to be functioning at the intersection of past and present. The basis for considering the image of a girl disguised as a man in the context of the cultural realities of modernity is provided by her progressive, "feministic" views. While in the case of anthropomorphic fiend the ground for this is his true awareness of these realities (because the devil is able to travel in time).

${ }^{58}$ Vynnychuk Y. (2015) Aptekar [The Pharmacist]. Kharkiv: Folio, p. 311 (in Ukrainian).

${ }^{59}$ Ibid, p. 304.

60 Shchytova-Romanchuk L. A. (2000) Tvorchist Hodvina v konteksti romantychnoho demonizmu [Godwin's creative activity in the context of romantic demonism] (PhD Thesis), Dnipropetrovsk: DDU, p. 6.

${ }^{61}$ Vynnychuk Y. (2015) Aptekar [The Pharmacist]. Kharkiv: Folio, p. 267 (in Ukrainian). 
Supporting Kalkbrenner's words that the moon makes women "... brawlers, flirts", Franz notes: "- as well as feminists... - What did you say? - Johan was surprised. - What the hell are feminists? - Ah, but these are the monsters who will make their appearance in two hundred years, laughed Franz" ${ }^{\prime 62}$.

Thus, the ambivalence of this pseudomorphic character of the Ukrainian writer's novel (as well as that of Yuliana-Lorenzo), is determined not only by the contradiction between his essence and appearance, but also by his simultaneous belonging to the cultural tradition of the past and present.

The narrator (Lukash Hulevich) is also a pseudomorphic character: the young man substitutes his late friend Martin. Before his death, the latter insisted on such a "performance": "All my papers and the stryiko's (uncle's) will are there. There's also some money there. I will all the same die, you can take advantage of this. Stryiko had no other relatives but me. You will say that you are me, Martin Airer from Salzburg" "63.

So Lukash becomes the owner of a pharmacy and still he has no rights for it. His image supplements the gallery of simulators, imitators of the novel: "Yuliana thought that Lukash is just living another life, Martin's life, as she lives the life of some non-existent Lorenzo, there are already three of them who live someone else's lives ...,"64.

Lukash is, in fact, an impostor, for he annexes another person's property, while obtaining material gain and status in society, which he would not have had under other circumstances. In this aspect, Y. Vynnychuk's pharmacist relates to pretenders of a wide cultural context who groundlessly appropriate someone else's belongings - the throne (self-proclaimed rulers), wealth (pseudo-rich man), the bride (pseudo-betrothed) and the like. A detailed review of these types is presented in the monograph "Pseudomorphic Characters of Ukrainian and Russian Literatures of the Late $18^{\text {th }}-1^{\text {st }}$ Half of the $19^{\text {th }} \mathrm{C}$. (in the Context of European Tradition)" ${ }^{\text {"65 }}$.

${ }^{62}$ Ibid, p. 226.

${ }^{63}$ Ibid, p. 18.

${ }^{64}$ Vynnychuk Y. (2015) Aptekar [The Pharmacist]. Kharkiv: Folio, p. 285 (in Ukrainian).

${ }^{65}$ Nikolova O. O. (2017) Psevdomorfni personazhi ukrainskoi ta rosiiskoi literatur kintsia XVIII - pershoyi polovyny XIX st. (u konteksti yevropeiskoyi tradytsii). [Pseudomorphic Characters of Ukrainian and Russian Literatures of the Late $18^{\text {th }}-$ 
In his function Lukash Hulevich is most similar to the pseudo-hero of a fairy tale, distinguished and characterized by V. Propp ${ }^{66}$, because he occupies the place of the one who is legally entitled to enjoy the benefits of life (in the fairy tale it is the throne and wife, in the piece by Y. Vynnychuk it is the title of the "royal" pharmacist).

However, this similarity is only a formal one. After all, Lukash, firstly, is not guilty of Martin's death, while a fabulous pseudo-hero kills the seeker, Martin dies at the hands of an unknown murderer. Secondly, he does not declare himself an heir to the pharmacist by his own will (pseudohero is driven by mercenary motives, Lukash executes the will of his dying friend). And finally, he gets no punishment after the resurrection of the true hero and his own exposure (Lukash's friends know about the swap and they all keep this secret). Thus, the pharmacist from the novel of the same name compares favourably with the impostors, since his substitution is imposed, noble, in no way connected with the deceitful and criminal methods of achieving the goal.

The analysis of the pseudomorphic characters of the novel by this Ukrainian writer in the context of cultural tradition makes it possible to draw conclusions about their specificity: all the pretenders in "The Pharmacist" feel much better in their mask than without it. The mask helps them to act according to their true needs and goals.

Yuliana disguised as a man lives a much more interesting, more fulfilling life than the one she would be destined to live as a girl: for comparison one can take the story of her twin sister, raped and murdered by rich young men ("Because she is nobody. She has no more rights for her life than any ants" ${ }^{, 67}$ ). In fact, it is only in the costume of a man that Yuliana becomes herself, she is a strong, determined, courageous, skilled surgeon, a fair executioner for those who put themselves above the law.

The devil in the image of Franz plunges into the very whirlpool of human passions, enjoying earthly revelry more than his existence in hell.

\footnotetext{
$1^{\text {st }}$ Half of the $19^{\text {th }}$ C. (in the Context of European Tradition)]. Zaporizhzhya : Zaporizkyi natsionalnyi universytet. Pp. 56-58 (in Ukrainian).

${ }^{66}$ Propp V. Y. (1946) Istoricheskije korni volshebnoj skazki [Historical roots of a Fairy-tale]. Leningrad : Izd-vo Leningradskogo gosudarstvennogo ordena Lenina universiteta, p. 137 (in Russian).

${ }^{67}$ Vynnychuk Y. (2015) Aptekar [The Pharmacist]. Kharkiv: Folio, p. 4 (in Ukrainian).
} 
"In hell, you know, everyone has their own occupation. Still, making tricks is much more fun than suffering near sinners' boilers" $"$.

When Lukash plays the role of his deceased friend Martin, he gets a possibility to help others, to test in practice and to improve his knowledge of medicine, he also finds true love.

Paradoxically, pseudomorphism provides Y. Vynnychuk's characters with the ability to realize their own essence, while, according to traditional views, a mask is to deprive one of one's self, level one's personality: through masking, cross-dressing one loses their identity. In many cultures of ancient times, this was reflected in various archaic ceremonies, where any ritual actions aimed at violating the correspondence between the true nature of a human and its formal presentation/reception (exchanging the clothes, covering-up the face, swapping status etc.) meant symbolic death ${ }^{69}$.

Here one can mention, for example, the calendar (Kronia, Saturnalia, Maslyana, carnivals, etc.) and social (initiations, marriage and so on) "transitional rituals", " "a mandatory component of which is a formal role inversion, substitution as a reflection of a permanent mutual transition of life and death. It is about temporarily role swapping between lords and slaves in Kronia and Saturnalia, cross-gender travesty, election of profane kings and popes, use of costumes / masks of animals, strangers, monsters, appearance of counterfeit brides at weddings, imitation of death that is vital for initiation, "carnival funerals", substitution of a person by their artificial image etc." $"$

In the context of the carnival cultural traditions pseudomorphic characters are typical functional types and represent one of those

${ }_{69}^{68}$ Ibid, p. 42.

69 Mednikova M. B. (2004) Fenomen maski v traditsionnoj kulture: simvolicheskaja priroda sposoba ritualnogo prevrashchenija [Phenomenon of a mask in traditional culture: symbolic character of the way of ritual metamorphosis]. Livejournal. (electronic journal). Retrieved from: https://svart-ulfr.livejournal.com/ 207940.html (accessed 12 January 2020).

${ }^{70}$ Gennep Arnold van. (2002) Obrjady perehoda: Sistema izuchenija obrjadov [Rituals of transition: system of studying the rituals]. Moskva: «Vostochnaja literatura» RAN, p. 15 (in Russian).

71 Nikolova O. O. (2017) Psevdomorfni personazhi ukrainskoi ta rosiiskoi literatur kintsia XVIII - pershoyi polovyny XIX st. (u konteksti yevropeiskoyi tradytsii). [Pseudomorphic Characters of Ukrainian and Russian Literatures of the Late $18^{\text {th }}-$ $1^{\text {st }}$ Half of the $19^{\text {th }}$ C. (in the Context of European Tradition)]. Zaporizhzhya : Zaporizkyi natsionalnyi universytet. P. 33 (in Ukrainian). 
significant connections that allow to include various synchronically and diachronically different phenomena into cultural comparative analysis (for example, ancient myths and rituals, folklore and literary texts).

Carnivalesque atmosphere in the artistic world of Y. Vynnychuk's novel is created not only with the help of introduction of pseudomorphic characters, but also by depictions of Morana's festivities, which are also intended to unite the past and the present in the mind of a conscious recipient. Morana's Day is associated with medieval carnivals, various carnival-type festivals, characterized in detail by M. Bakhtin as well as with the contemporary Halloween.

M. Bakhtin points out that "carnival life" is "a life removed from its usual track, to a certain extent its "life inside out", "inverse world" ("monde a l'envers"),"72, "carnival brings together, unites, betroths and combines the holy and the profane, the high and the low, the grandiose and the miserable, the reasonable and the unreasonable, etc."73, "everything that was closed, disconnected, distant from each other by the beyond-carnival hierarchical worldview enters into carnival contacts and combination",74.

A whole chapter in the novel by Y. Vynnychuk is devoted to Morana's Day, the first part of which is almost entirely based on reminiscences of M. Bakhtin's famous works. On this day Lviv's inhabitants dress up in the costumes of the dead, their ancestors, thus creating the illusion of their resurrection, which, in its turn, is to symbolize the spring revival of nature after winter. Simple laymen also have fun and enjoy themselves, arranging a kind of large-scale performance with the participation of different carnival monsters representatives of the dark world (witches, ghouls, devils, etc.).

"People needed entertainment, possibility to spill out all their passions and to sink into a reverie at least for a while. The holiday of Morana, when the dead were remembered, did not in any way resemble the Day of all the dead, when the dried flowers, fallen leaves, rains, gloomy days and long nights cause fatigue and desire to fall asleep, when

72 Bakhtin M. M. (2002) Problemy poetiki Dostoevskogo [Problems of Dostoevsky's poetics]. Moskva-Augsburg : «Im-Werden-Verlag», 2002, p. 71 (in Russian).

Bakhtin M. M. (2002) Problemy poetiki Dostoevskogo [Problems of Dostoevsky's poetics]. Moskva-Augsburg : «Im-Werden-Verlag», 2002, p. 72 (in Russian).

${ }^{74}$ Ibid, p. 72. 
the end of the year looks like the end of life... But it is perceived differently in March, when nature wakes up and manifests itself in colors, smells and sounds. Spring also awakens in the souls of people... and everyone prepared a mask of their ancestor ... But it was not only by clothes and a mask that they depicted forefathers, they also mentioned some customs or features of the deceased, their language, behavior ... a certain category of philistines turned this holiday into a parody, putting on whatever turns up, in particular, sometimes some ugly masks, made in haste ... Animals' and birds' heads... or snouts of some sort of fiends with bloody fangs prevailed among such masks"75.

At the same time, such masking can be considered in the context of Slavic rituals. For example, characterizing the tradition of dressing up for yuletide, A. Baiburin notes that "different groups of maskers are united by one common characteristic: they are all connected with the sphere of the $\mathrm{f}$ o e and opposed to the $\mathrm{f} \mathrm{r}$ i e $\mathrm{n} \mathrm{d}$ in all planes topical for the group: social (... farriers, soldiers), ethnic (Romas, Moors, Turks), belonging to nonhuman, animal sphere (bull, goat, bear, etc.), witchcraft (devil, evil spirits, etc.), the world of death (the dead, forefathers) and generally the distant land ("people of the road"). By the well-known analogy, the maskers exemplify a specific parade of representatives of an alien world",76.

During Morana holiday, all residents of Lviv temporarily turn into pseudomorphic characters: people feign the dead, representatives of the animal or supernatural worlds. Pseudomorphism transforms from the exception into the norm.

Everything stated above quite vividly manifests, on the one hand, the significance of pseudomorphic characters in Y. Vynnychuk's novel, and, on the other hand, the expediency of considering "The Pharmacist" in the broad context of cultural tradition.

\section{CONCLUSIONS}

Thus, it is obvious that cultural aspect of philological analysis is relevant and significant. The scrutiny of scientific works proves that the

75 Vynnychuk Y. (2015) Aptekar [The Pharmacist]. Kharkiv: Folio, pp. 257259 (in Ukrainian).

76 Baiburin A. K. (1993) Ritual v traditsyonnoj kulture. Strukturnosemanticheskij analis vostochoslavijanskikh obrjadov [Ritual in traditional culture. Structural and semantic analysis of East-slavic rites]. Sankt-Peterburg : Nauka, p. 132 (in Russian). 
pseudomorphic characters are among the phenomena that have a longterm potential for cultural study in the realm of philology. Such characters' main feature is their falsehood created by the violation of correspondence between their essence and their formal presentation/ reception (they acquire alien appearance, impersonate others, they are perceived inadequately). The means of creating pseudomorphism are travesty, reincarnation, verbal-positional pretense, situational mismatch (coincidence, confusion, etc.). Such images are associated with the expression of universal beliefs about the contradictions of the visible and the true, which in many forms is reflected in the cultures of many countries of the world.

There are different preudomorphic characters in "The Pharmacist" by Y. Vynnychuk: 1) Yuliana-Lorenzo (a girl who performs the role of a young man); 2) devil-Franz, who stays among people in human form; 3) self-proclaimed pharmacist Lukash, who pretends to be Martin (his deceased friend).

All the images naturally fit into the cultural context: as for the first character, it is connected with a cross-gender travesty of ancient rites, dissemination of this motif in folklore and literature (works by G. Boccaccio, Lope de Vega, T. de Molina, C. Goldoni, W. Shakespeare, etc.); as for the second one, it reflects the universal beliefs in the possibility of humanization of the supernatural creatures that are logically reflected in art in general and literature in particular (works by J. W. Goethe, J. Cazotte, A. von Chamisso, M. Gogol, L. Andreyev, M. Bulgakov and others); as for the third protagonist, it shows correlation with the phenomenon of imposture. Depiction of Morana's holiday is to be examined in the light of carnivalesque culture.

At the same time the pseudomorphic characters of the novel under study have their specific features: they are modernized and creatively transformed in accordance with the modern culture realia.

\section{SUMMARY}

The article deals with the study of correlation between the pseudomorphic characters of Y. Vynnychuk's novel "The Pharmacist" and the cultural tradition. The cultural aspect of philological analysis makes it possible to elucidate this issue. The main feature of pseudomorphic characters is the contradiction between their essence and formal presentation/reception (they impersonate others/are inadequately perceived). Several pseudomorphic images of the book are considered here. 
The first one is a girl Yuliana by name, who pretends to be a young man Lorenzo. The second image is that of the devil who hides behind the mask of a common human. The third pseudomorphic character is the pharmacist Lukash, who plays the role of Martin (his deceased friend). All the images naturally fit into the cultural context: as for the first character, it is connected with a cross-gender travesty of ancient rites, dissemination of this motif in folklore and literature; as for the second one, it reflects the universal beliefs in the possibility of humanization of the supernatural creatures that are logically reflected in art in general and literature in particular; as for the third protagonist, it shows correlation with the phenomenon of imposture. It is advisable to consider the images of Morana holiday, during which the inhabitants of the city hide behind the masks of their dead relatives or monsters, in the light of the carnivalesque cultural traditions. At the same time, the pseudomorphic characters of the novel under study have their own peculiarities: they are modernized and creatively transformed according to the realia of modern culture.

\section{REFERENCES}

1. Simbirtseva N. A. (2007) Bytije literaturnokhudozhestvennogo proizvedenija: kulturologicheskij aspect [Functioning of a work of fiction: culturological aspect]. Vestnik Chelyabinskogo gosudarstvennogo universiteta, no. 14. Pp. 28-34.

2. Betsenko T. (2017) Vydy analizu khudozhnoho tekstu [Types of a literary text analysis]. Visnyk Lvivskoho universytetu. Seriya filolohichna, vol. 64, ch II. Pp. 239-244.

3. Komarova L. I. Sovremennyje podhody $\mathrm{k}$ izucheniju hudozhestvennogo teksta [Modern approaches to studying a literary text]. Cyberleninka (electronic journal). Retrieved from: https://cyberleninka.ru/ article/n/sovremennye-podhody-k-izucheniyu-hudozhestvennogo-teksta (accessed: 24 January 2020).

4. Nikolova O. O. (2017) Psevdomorfni personazhi ukrainskoi ta rosiiskoi literatur kintsia XVIII - pershoyi polovyny XIX st. (u konteksti yevropeiskoyi tradytsii). [Pseudomorphic Characters of Ukrainian and Russian Literatures of the Late $18^{\text {th }}-1^{\text {st }}$ Half of the $19^{\text {th }} \mathrm{C}$. (in the Context of European Tradition)]. Zaporizhzhya : Zaporizkyi natsionalnyi universytet. 450 p. (in Ukrainian).

5. Osinovskaya O. S. Kross-gendernoje pereodevanije v pjesah U. Shekspira [Cross-gender change of attire in plays by W.Shakespeare]. Literatures and Languages (electronic journal), vol. 21. Retrieved from: 
http://svr-lit.ru/svr-lit/articles/english/osinovskaya-kross-gendernoe-pere odevanie.htm. (accessed: 31 January 2020).

6. Frazer J. G. (2001) Zolotaja vetv: issledovanije magii i religii $v$ dvuh tomah [Golden bough: a study of magic and religion in two volumes]. Moskva : TERRA - Knizhnyj klub, vol. 1.528 p. (in Russian).

7. Cornford F. M. The origin of Attic comedy. London : EDWARD ARNOLD, 1914. 252 p.

8. Bakhtin M. M. (1990) Tvorchestvo Fransua Rable $i$ narodnaya kultura Srednevekovya i Renessansa [The Creative Art of François Rabelais and Folk Culture of the Middle Ages and the Renaissance]. Moskva: Hudozhestvennaja literatura. 543 p. (in Russian).

9. Sazonovich I. P. (2011) Pesni o devushke-voine $i$ byliny o Stavre Godinoviche : issledovanije po istorii razvitija slavjano-russkogo eposa [Songs about a girl-warrior and epics about Stavr Godunovich]. Moskva : Kniga po Trebovaniju, 183 p. (in Russian).

10. Krzhizhanovskiy Y. (1963) Devushka-yunosha (k istorii motiva «peremena pola») [A girl-boy (history of the "gender change" motive)]. Russkij folklor, vol. 8. Pp. 56-66.

11. Uliura A. (2004) Henderno markyrovannoje pereodevanije kak komicheskoje (na materiale russkoj klassicheskoj literatury) [Gendermarked cross-dressing as the comic (case study: Russian classical literature)]. «Dóxa / DOKSA». Zbirnyk naukovykh prats z filosofii ta filolohii, vol. 5. Pp. 335-342.

12. Krokhmalnyi R. O. (2005) Metamorfoza i tekst: semantychna, strukturotvorcha $i$ svitohlyadna rol pereminy khudozhnoho obrazu [Metamorphosis and the text: semantic, structure-making and worldview role of changing a literary image]. Lviv : Vydavnychyi tsentr Lvivskoho nats. un-tu imeni Ivana Franka. 424 p. (in Ukrainian).

13. Makarenko Y. K. (2002) Zhanrovyj aspekt sjuzheta samozvanstva $v$ russkoy dramaturgii $i$ istoriografii kontsa XVIII - pervoj treti XIX $v v$. [The genre aspect of the plot about impostor in Russian dramaturgy and historiographics of the late XVIII - early XIX centuries] (PhD Thesis), Tomsk, $21 \mathrm{p}$.

14. Lazutkina M. G. (2003) Formirovanije hudozhestvennogo obraza samozvantsa Lzhedmitrija I v russkoj literature XVII - XIX vekov [Formation of a fictional image of the impostor Pseudo-Dmitrij I in Russian Literature of XVII - XIX centuries] (PhD Thesis), Moskva, 19 p.

15. Vitiak Y. (2016) Literaturna farmatsevtyka. Mizh panatseieiu i platsebo [Literary pharmaceuticals. Between the panacea and placebo]. Literaturnyi Ternopil, no 2, pp. 83-84. 
16. Kotsarev O. «Aptekar» Vynnychuka: vidmy, katuvannia, strashni mahichni knyzhky, balzamy, otruty i troshky seksu ["The Pharmacist" by Vynnychuk: witches, tortures, horrible magic books, balms, poisons and a little sex]. Тексти.org.иа [Texts.org.ua] (electronic journal). Retrieved from: http://texty.org.ua/pg/article/editorial/ read/63534/Aptekar_Vynnychuka_vidmy_katuvanna_strashni_magichni_ knyzhky (accessed 10 January 2020).

17. Litvinchuk T. V. (2017) Lokus domu v serednovichnomu Lvovi (na materiali romanu «Aptekar» Yuriia Vynnychuka) [Locus of home in medieval Lviv (Yurii Vynnychuk's "The Pharmacist": case study)]. Literaturoznavchi studii, vol. 1(2), pp. 32-40.

18. Panchenko A. (2016) Chytajem ukrainskoje: Retsenzija na knigu «Aptekar» Yurija Vinnichuka [Reading Ukrainian: review of the book "The Pharmacist" by Yurii Vynnychuk]. Segodnia [Today] (electronic journal). Retrieved from: https://ukr.segodnya.ua/lifestyle/ showbiz/chitaem-ukrainskoe-recenziya-na-knigu-aptekar-yuriya-vinnic huka-701314.html (accessed 20 December 2019).

19. Tsikhotskii I., Borosovska I. (2018) Starolvivska beletrystyka Yuriia Vynnychuka: avtorska kontseptsiya movnoho istoryzmu (na materiali romanu «Aptekar») [Old-Lviv belles-lettres by Yurii Vynnychuk: author's concept of language historicism (novel "The Pharmacists": case study)]. Visnyk Lvivskoho universytetu. Seriya filolohichna, vol. 68, pp. 30-47.

20. Cherniuk S. L. (2016) Komunikatsiina ryzomatyka romanu Y. Vynnychuka «Aptekar» [Communication rhizomatics of Yurii Vynnychuk's novel "The Pharmacist"]. Nuakovi pratsi Chornomorskogo derzhavnoho universytetu imeni Petra Mohyly kompleksu "KyevoMohylianska Akademiia”, vol. 276, no. 264, pp. 121-126. Retrieved from: http://nbuv.gov.ua/UJRN/Npchdufl_2016_276_264_23 (accessed 11 November 2019).

21. Vynnychuk Y. (2015) Aptekar [The Pharmacist]. Kharkiv: Folio, 318 p. (in Ukrainian).

22. Propp V. Y. (2000) Russkije agrarnyje prazdniki. Opyt istoriko-etnograficheskogo issledovanija [Russian agrarian holidays. Experience of historical and ethnographic research]. Moskva : Labirint, 192 p. (in Russian).

23. Freidenberg O. M. (1997) Poetika sjuzheta $i$ zhanra [Poetics of plot and genre]. Moskva : Labirint, 448 p. (in Russian). 
24. Miller O. F. (1869) Ilja Muromets $i$ bogatyrstvo Kijevskoje [Ilya Muromets and Kyiv bogatyrs]. Sankt-Peterburg : Tipografija N. N. Mikhajlova, 830 p. (in Russian).

25. Franko I. (1984) Divchyna-voiachka [A girl-warrior]. Zibrannia tvoriv u 50-ty $t$. [Collection of works in 50 volumes]. Kyiv : Naukova dumka, vol. 42, pp. 225-229.

26. Meletinskiy Ye. (1990) Istoricheskaja poetika novelly [Historical poetics of novella]. Moskva: Nauka, 278 p. (in Russian).

27. Veselovsky A. N. (1870) Starinnyj teatr v Yevrope [Ancient theatre in Europe]. Moskva : V tipografii P. Bakhmeteva, 419 p. (in Russian).

28. Anikst A. (1989) Dvenadtsataya noch, ili Chto ugodno [Twelfth Night or What you will]. Angliyskaya komediya XVII XVIII vekov : antologiya [English comedy of 17th-18th centuries]. Moskva: Vysshaya shkola, pp. 735 - 746.

29. Andreyev M. L., Khlodovskiy R. I. (1988) Italyanskaya literatura zrelogo i pozdnego Vozrozhdeniya [Italian literature of high and late Renaissance]. Moskva : Nauka, 296 p. (in Russian).

30. Shchytova-Romanchuk L. A. (2000) Tvorchist Hodvina v konteksti romantychnoho demonizmu [Godwin's creative activity in the context of romantic demonism] (PhD Thesis), Dnipropetrovsk: DDU, $20 \mathrm{p}$.

31. Propp V. Y. (1946) Istoricheskije korni volshebnoj skazki [Historical roots of a Fairy-tale]. Leningrad : Izd-vo Leningradskogo gosudarstvennogo ordena Lenina universiteta, 337 p. (in Russian).

32. Mednikova M. B. (2004) Fenomen maski v traditsionnoj kulture: simvolicheskaja priroda sposoba ritualnogo prevrashchenija [Phenomenon of a mask in traditional culture: symbolic character of the way of ritual metamorphosis]. Livejournal. (electronic journal). Retrieved from: https://svart-ulfr.livejournal.com/207940.html (accessed 12 January 2020).

33. Gennep Arnold van. (2002) Obrjady perehoda: Sistema izuchenija obrjadov [Rituals of transition: system of studying the rituals]. Moskva : «Vostochnaja literatura» RAN, 198 p. (in Russian).

34. Bakhtin M. M. (2002) Problemy poetiki Dostoevskogo [Problems of Dostoevsky's poetics]. Moskva-Augsburg : «Im-WerdenVerlag», 2002, 167 p. (in Russian).

35. Baiburin A. K. (1993) Ritual v traditsyonnoj kulture. Strukturno-semanticheskij analis vostochoslavijanskikh obrjadov [Ritual 
in traditional culture. Structural and semantic analysis of East-slavic rites]. Sankt-Peterburg : Nauka, 240 p. (in Russian).

Information about the authors:

Oleksandra Nikolova,

Doctor of Philology, Associate Professor (Dotcent), Professor at the Chair of German Philology and Translation, Zaporizhzhia National University 66, Zhukovski str., Zaporizhzhia, 69600, Ukraine ORCID ID: orcid.org/0000-0002-2327-1941

Kateryna Vasylyna, Candidate of Philology, Associate Professor (Dotcent), Associate Professor at the Chair of English Philology,

Zaporizhzhia National University

66, Zhukovski str., Zaporizhzhia, 69600, Ukraine ORCID ID: orcid.org/0000-0002-7885-5418 